論文

GFRP 보강 철근콘크리트 합성부재의 구조적 거동

이승식 ${ }^{*}$ 주형중 ${ }^{* *}$, 강인규 ${ }^{* * *}$, 윤순종 ${ }^{* * *+}$

\title{
Structural Behavior of the Reinforced Concrete Filled GFRP Tube
}

\author{
Seungsik Lee*, Hyung-Joong Joo ${ }^{* *}$, In-Kyu Kang ${ }^{* * *}$, and Soon-Jong Yoon ${ }^{* * *+}$
}

\begin{abstract}
Recently, to solve the problems associated with the neutralization and corrosion of reinforced concrete compression members, the structural configurations such as CFFT (Concrete Filled GFRP Tube) and RCFFT (Reinforced Concrete Filled GFRR Tube) have been developed and applied to main members of civil engineering structure. These members can increase structural performance in terms of structural stability, ductility as well as chemical resistance compared with conventional concrete structural members. Many researches in numerous institutions to predict the load carrying capacity of the concrete compression member strengthened with FRP materials have been conducted and they have been suggested an equation for the prediction of the load carrying capacity of the members. Through the review of the research results, it was found that their results are similar each other. Moreover, it was also found that the results are not directly applicable to our specimens since the results are largely depended upon the member configurations. Also, since the accurate design criteria for the RC members strengthened with FRP such as RCFFT have not been established properly, relevant theoretical and experimental investigations must be conducted for the application to the practical structures. In this study, structural behavior of RCFFT was evaluated through compressive and quasi-static flexural tests in order to formulate design criteria for the structural design. In addition, the RCFFT members were also investigated to examine their confinement effect and the equations capable of estimating the compressive ultimate strength and flexural stiffness of the RCFFT members were proposed.
\end{abstract}

\section{초 록}

최근 토목분야에서 철근콘크리트 압축재에 발생하고 있는 부식, 중성화 등의 문제점을 해결하기 위해 섬유강화복합재로 외 부를 보강한 합성부재가 개발되어 적용되고 있다. 이러한 합성부재는 외부를 섬유강화플라스틱으로 보강하고 있어 부재 전체 의 구조적 성능을 향상시킬 뿐만 아니라 내화학성이 우수하여 기존 콘크리트 부재와 비교할 때 내구성이 향상된다. 그러나 복합재로 외부를 보강한 콘크리트 합성부재에 대한 기존 연구자료들은 구조적 거동해석에서 큰 차이가 없이 유사한 결과를 보여주었으나 그 결과가 부재의 단면구성과 크게 관계되기 때문에 이 연구에 직접적으로 적용하는데는 어려움이 있고, 또한 설계기준으로 적용하기에는 여전히 미흡한 실정이다. 이 연구에서는 RCFFT 부재의 설계규준 마련을 위한 기초자료를 확보하 기 위해 압축 및 준정적 휨실험을 수행하여 구조적 거동을 조사하였고, 압축강도를 추정할 수 있는 근사식을 제안하였으며, 휨강성을 예측할 수 있도록 하였다.

Key Words : CFFT (Concrete Filled FRP Tube), RCFFT (Reinforced CFFT), 압축재(Compression Members), 실험(Experiment), 휨강성(Flexural Stiffness)

\footnotetext{
* 한국해양과학기술진흥원

** 홍익대학교 대학원 토목공학과 구조공학전공

*** (주)브니엘컨설턴트

****+ 홍익대학교 토목공학과 구조공학전공 교신저자(E-mail:sjyoon@hongik.ac.kr)
} 


\section{1. 서 론}

1990년대 이후 FRP 제조기술이 급속히 발전함에 따라 건 설분야에서도 $\mathrm{FRP}$ 의 활용이 증가되고 있다. 강성이 우수한 탄소섬유 시트나 유리섬유 패널 등을 사용하여 철근콘크리트 구조물의 균열제어, 방수 등 기초적인 보수 단계에서 벗어나 FRP re-bar, Sheet, Grid 등을 사용한 구조물의 보강, FRP Wrapping을 사용한 보수보강 기술이 연구 개발 중에 있으며 일부 적용되고 있다[1]. 그러나 FRP 구조부재에 대한 명확한 해석 및 설계규준이 마련되어 있지 않으며, 구조물에 적용할 경우 해석 및 설계를 위한 변수가 다양하기 때문에 자체실험 등을 통하여 부재의 성능을 확보한 후 제한적으로 사용하고 있는 실정이다. 즉, FRP는 재료적 성능에서 뛰어난 장점을 보유하고 있음에도 불구하고 그 적용성은 상당히 낮은 단계 에 머물러 있다.

건설분야에서 FRP는 경제성을 이유로 GFRP (Glass Fiber Reinforced Polymer)가 주로 사용되고 있으며, 강재에 비해 비교적 낮은 강성으로 독립적인 구조부재로 사용하기 보다는 주로 콘크리트 보강재로 적용되고 있다. FRP를 콘크리트 보 강재로 사용한 대표적인 부재는 표면을 FRP로 보강하여 내 구성을 향상시킨 CFFT (Concrete Filled FRP Tube)이다. CFFT는 화학적 내구성이 강한 $\mathrm{FRP}$ 를 통해 부재 전체의 내 구성을 향상시킬 뿐만 아니라 압축재로 활용할 경우 내부 콘 크리트를 구속하여 하중저항성능이 향상되기 때문에 상부하 중을 지반에 전달하기 위한 교각(Pier), 말뚝(Pile) 등의 압축 재로 사용하기 위한 연구가 활발히 진행되고 있다.

건설분야에 사용되는 압축재는 일반적으로 압축하중 뿐만 아니라 수평하중 및 편심 등의 영향으로 인한 휨에 대해서도 적절한 보강이 필요하다. 최근 CFFT 부재의 휨에 대한 저항 능력을 향상시키기 위해 내부에 철근을 삽입한 RCFFT (Reinforced Concrete Filled FRP Tube)가 교량구조물에 적용 된 바 있다(Fig.1 참조).

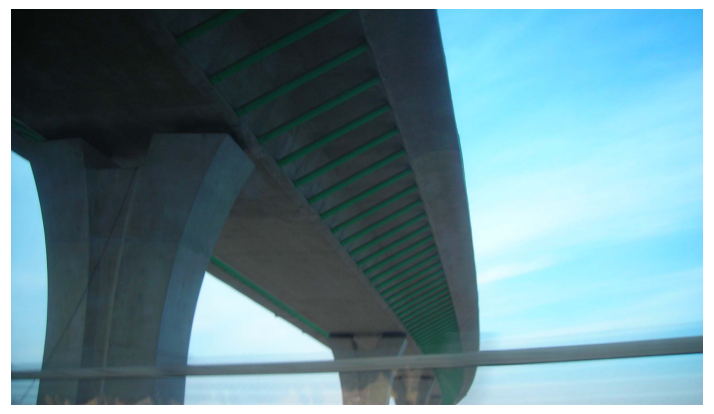

Fig. 1 PSC box girder bridge with RCFFT struts [2].

RCFFT 부재는 기존 콘크리트의 미관불량, 강재의 부식과 유지관리의 어려움, 용접 연결부의 피로문제 등을 효과적으로
개선할 수 있는 것으로 평가되고 있으나 구조적 거동에 대한 연구자료가 부족하여 설계단계에서 부재의 하중저항성능을 적절히 반영하지 못하고 있다. 따라서 효율적인 설계를 위해 서는 RCFFT 부재의 구조적 거동에 대한 연구가 선행되어야 한다.

이 연구에서는 RCFFT 부재에 대한 구조적 거동을 조사 하기 위해 구성재료에 대한 역학적 성질을 실험을 통해 결정 하였고, 일축압축실험 및 준정적 휨실험을 수행하였으며, 실 험결과를 분석하여 RCFFT 부재에 대한 압축강도 및 휨강성 을 추정할 수 있도록 하였다.

\section{RCFFT의 구성 및 특징}

CFFT는 압축성능을 향상시키기 위해 콘크리트 외부에 $\mathrm{FRP}$ 를 보강한 압축재이다. 그러나 건설분야에 적용되고 있 는 대부분의 압축재는 압축과 함께 휨을 받는 Beam-column 으로 CFFT 부재를 현장에 적용하기 위해서는 적절한 휨보강 방안이 필요하다. CFFT 부재의 휨에 대한 보강방안으로 내 부 콘크리트에 철근을 삽입한 부재가 RCFFT 부재이며, 단면 구성은 Fig. 2에 나타내었다.

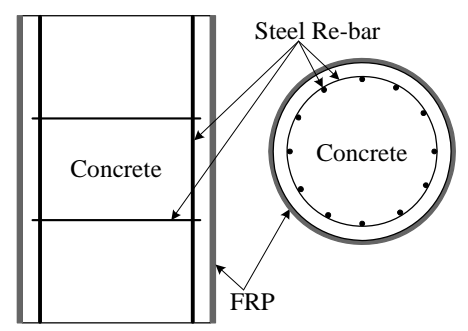

Fig. 2 Component of RCFFT member cross-section.

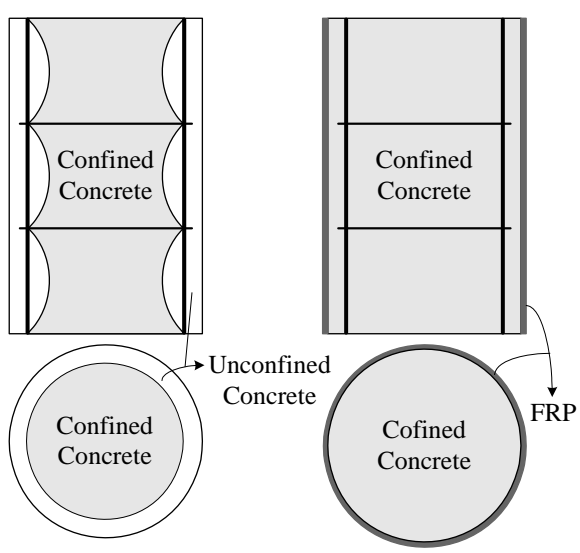

(a)

(b)

Fig. 3 Confinement effect. 
또한, Fig. 3(a)에 나타낸 바와 같이 횡방향철근에 의한 심 부콘크리트의 구속효과는 종방향철근 내부로 한정되지만 외 부에 FRP를 통해 보강할 경우 Fig. 3(b)에 나타낸 바와 같이 콘크리트 전단면적을 모두 유효단면으로 고려할 수 있어 동 일한 하중조건에서 철근량을 감소시키거나 단면의 축소가 가 능하다.

\section{RCFFT 부재의 압축강도}

\section{1 실험체 제작 및 재료의 역학적 성질}

기존 연구에 따르면 FRP로 구속된 콘크리트 합성부재의 압축강도에 영향을 미치는 주요변수로는 FRP의 역학적 성 질, 단면의 형태, 콘크리트의 강도 등이 있으나 이 연구에서 는 FRP 보강에 의한 구조적 거동 특성을 조사하기 위해 $\mathrm{FRP}$ 의 두께를 변화시켜 RCFFT실험체를 제작하였다. FRP의 두께를 제외한 실험체의 직경과 높이는 각각 $300 \mathrm{~mm}, 600 \mathrm{~mm}$ 이고, FRP구속에 따른 압축성능 증진효과를 비교, 검토하기 위해 FRP로 보강하지 않은 철근콘크리트 실험체를 추가 제 작하였다. 실험체의 구성 및 치수는 Fig. 4에 나타내었고, 실 험체의 종류 및 변수는 Table 1에 정리하여 나타내었다.

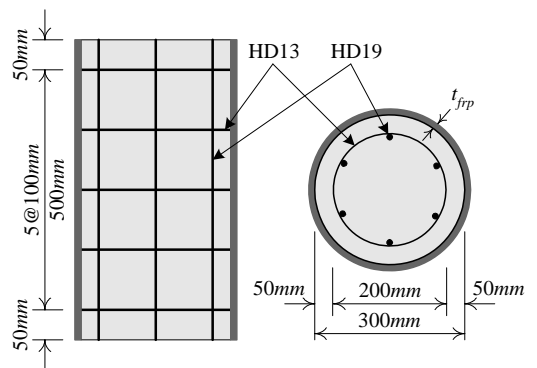

Fig. 4 Details of RCFFT specimens.

Fig. 4에 나타낸 RCFFT 실험체는 적층각이 $20^{\circ}$ 인 필라멘 트 와인딩으로 제작한 GFRP 원통관에 철근을 배근하고 콘 크리트를 타설하여 제작하였다. 콘크리트 강도 $\left(f_{c o}\right)$ 는 $40 \mathrm{MPa}$ 이고, 철근(HD13, HD19)은 상용제품을 사용하였으며, 항복 강도 및 탄성계수는 각각 $400 \mathrm{MPa}, 200 \mathrm{GPa}$ 이다. 또한, 외부 보강용으로 사용한 필라멘트 와인딩 FRP는 직접 Split disk 시험을 통해 조사하였으며, 평균 파단강도와 탄성계수는 각 각 $586 \mathrm{MPa}, 46 \mathrm{GPa}$ 로 조사되었다.

Table 1 Test parameter

\begin{tabular}{c|c|c|c}
\hline \hline No. & $\begin{array}{c}\text { FRP 두께 } \\
(\mathrm{mm})\end{array}$ & $\begin{array}{c}\text { 종방향철근 개수 } \\
(\mathrm{ea})\end{array}$ & $\begin{array}{c}\text { 횡방향철근 간격 } \\
(\mathrm{mm})\end{array}$ \\
\hline $\mathrm{RV}_{0}$ & 0 & 6 & 100 \\
\hline $\mathrm{RV}_{1}$ & 1.25 & 6 & 100 \\
\hline $\mathrm{RV}_{2}$ & 2.50 & 6 & 100 \\
\hline $\mathrm{RV}_{3}$ & 5.00 & 6 & 100 \\
\hline \hline
\end{tabular}

\section{2 일축압축 실험결과}

RCFFT 부재의 압축실험은 모두 일축압축실험으로 수행하 였고, 하중은 하중재하판을 별도로 설치하여 FRP의 내부 콘크 리트에만 하중이 재하되도록 하였으며, 실험체의 축방향 변위 를 계측할 수 있도록 LVDT를 설치하였다.

실험결과 RCFFT 및 $\mathrm{FRP}$ 를 보강하지 않은 RC 실험체의 파괴모양은 Fig. 5에 나타내었다. Fig. 5에서 각 실험체의 파괴 는 외부에 보강된 FRP가 파단되면서 최종 파괴에 이르렀고, $\mathrm{FRP}$ 의 파단은 중앙과 하중이 재하되는 상단에서 발생하였다. 시편 상단에서 외부 보강 FRP가 파단되는 현상은 필라멘트 와 인딩 FRP의 특성상 보강섬유를 감아서 제작하기 때문에 실험 체 상단 단부 $\mathrm{FRP}$ 에서 보강섬유가 절단된 불연속면이 존재하 게 된다. 따라서, 중앙부의 콘크리트에 비해 상단부 콘크리트 는 비교적 FRP에 의해 구속되는 정도가 작기 때문에 상단부에 서 파괴가 발생하는 것으로 생각된다. 그러나 FRP의 파괴 위 치가 중앙부, 상부에서 번갈아 발생하는 것으로 나타났고, 이 러한 현상으로부터 상단부에 FRP에 의한 구속효과는 불연속면 이 존재하더라도 크게 저하되지 않는 것으로 판단되며, 비교적 작은 압축강도의 예측은 설계를 위한 데이터로 적용하는데는 큰 문제가 없을 것으로 생각된다.

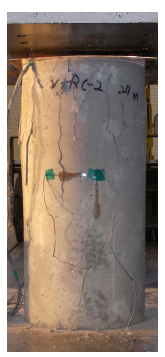

(a) RV0

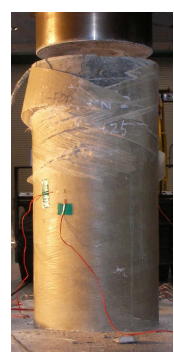

(b) RV1

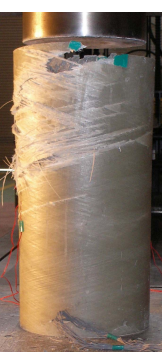

(c) RV2

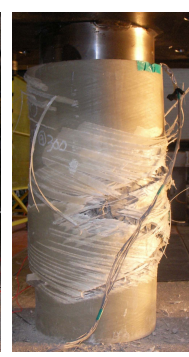

(d) RV3
Fig. 5 Failure mode.

일축압축 실험결과 설치한 계측기로부터 실험체의 축방향 하중-변위 관계를 Fig. 6에 비교하여 나타내었고, 각 시편에서 조사된 최대하중을 Table 2에 나타내었다. 실험결과 보강두께 의 증가는 RCFFT 부재의 하중저항성능을 크게 향상시키는 것 으로 나타났다.

Table 2에서 $\mathrm{RV}_{3}, \mathrm{RV}_{2}$ 실험체의 최대하중의 차는 $1,730 \mathrm{kN}$ 이 고, $\mathrm{RV}_{2}, \mathrm{RV}_{1}$ 실험체의 최대하중의 차는 $1,786 \mathrm{kN}$ 으로 유사하게 확인되어 보강두께와 대응하여 선형으로 증가하였다. 그러나 보강하지 않은 $\mathrm{RV}_{0}$ 실험체와 보강두께가 1.25 인 $\mathrm{RV}_{1}$ 실험체를 비교할 경우 $\mathrm{RV}_{3}, \mathrm{RV}_{2}, \mathrm{RV}_{1}$ 의 최대하중의 증가폭보다 둔화되 는 경향을 보였으며, 이러한 현상은 띠철근에 의한 구속효과가 FRP에 의한 구속효과보다 크기 때문에 FRP에 의한 구속이 전 단면에 대해 효과적으로 이루어지지 않은 것으로 판단되며 이 러한 현상을 분석하여 이 연구에서는 RCFFT에 대한 극한강도 를 추정할 수 있도록 하였다. 


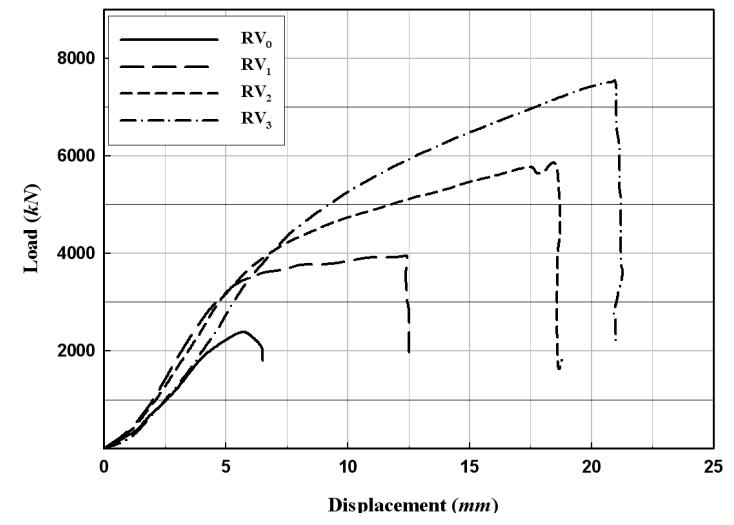

Fig. 6 Load vs. axial displacement.

Table 2 Test results

\begin{tabular}{c|c|c|c|c}
\hline \hline No. & $\mathrm{RV}_{0}$ & $\mathrm{RV}_{1}$ & $\mathrm{RV}_{2}$ & $\mathrm{RV}_{3}$ \\
\hline 최대하중 $(k N)$ & 2399.8 & 3937.8 & 5724.5 & 7454.0 \\
\hline
\end{tabular}

\subsection{RCFFT 부재의 압축강도 예측}

RCFFT 부재는 기존 노후 구조물에 대한 보강공법이 아 닌 복합신소재를 적용한 신설 구조부재로서 이러한 압축재에 대한 연구는 Lin 등에 의해 실험적 연구가 수행된 바 있다 [3]. Lin 등은 공시체 크기 $(100 \mathrm{~mm} \times 200 \mathrm{~mm})$ 의 무근콘크리트, 철근콘크리트, $\mathrm{CFFT}, \mathrm{RCFFT}$ 실험체를 각각 제작하여 일축 압축실험을 수행하고, 실험결과로부터 RCFFT 부재에 대한 압축응력은 무근콘크리트의 압축응력과 철근에 의한 압축응 력 증가분, FRP 구속효과에 의한 압축응력 증가분을 산술적 으로 더하여 결정할 수 있다는 결론을 제시하였다. Lin 등의 연구결과에 의한 $\mathrm{CFFT}$ 의 압축응력을 식으로 표현하면 식 (1)과 같이 나타낼 수 있다[3].

$$
f_{\text {RCFFT }}=f_{c o}+f_{s c b}+f_{c c b}
$$

식 (1)에서 $f_{c o}, f_{s c b}, f_{c c b}$ 는 각각 무근콘크리트의 압축응 력, 철근에 의한 압축응력 증가분, FRP 구속효과에 의한 압 축응력 증가분을 의미하며, 식 (1)을 단면적을 고려한 하중으 로 표현하면 식 (2)와 같이 나타낼 수 있다.

$$
P_{R C F F T}=P_{u}+\left(f_{c c}-f_{c o}\right) A_{g}
$$

식 (2)에서 $A_{g}$ 는 콘크리트의 면적, $P_{u}$ 는 철근콘크리트 압 축재의 극한하중이고, $f_{c c}$ 는 $\mathrm{FRP}$ 에 의해 구속된 콘크리트의 압축응력으로 결국 우측 두 번째 항은 FRP의 구속에 의한 하중증가분을 나타낸다. 또한, $P$ 는 횡방향철근에 의해 효과 적으로 구속된 것으로 가정하여 유효구속계수(Effective confining coefficient) 4.1을 도입하고, 구속효과는 횡바향철근 내부의 심부콘크리트에만 작용하는 것으로 가정하면 식 (3)과 같이 나타낼 수 있다[6].

$$
P_{u}=0.85 f_{c o} A_{c c}+8.2 \frac{f_{y} A_{s p}}{d_{s} s}+f_{y} A_{s t}
$$

식 (3)에서 $A c c$ 는 심부콘크리트의 면적, $f_{y}$ 는 철근의 항복 응력, $A_{s p}$ 는 횡방향철근의 단면적, $d s$ 는 심부콘크리트의 직경, $s$ 는 횡방향철근의 간격, $A_{s t}$ 는 종방향 철근의 단면적이다. 식 (3)에서 첫 번째 항은 무근콘크리트의 압축력이고, 두 번째 항은 횡방향철근에 의한 구속효과로서 나선철근의 구속효과 에 의한 압축력의 증가분이며, 세 번째 항은 종방향 철근의 압축력이다. 따라서 식 (3)에서 나타내고 있는 철근콘크리트 의 압축하중은 콘크리트 압축력에 증가요인을 산술적으로 합 한 것이며, 콘크리트 피복은 유효단면에서 제외하고 있다. 그 러나 FRP에 의한 구속이 철근콘크리트 압축재의 최 외각층 에 존재한다면 피복두께 또한 유효단면의 일부가 되어 압축 강도는 더욱 증가될 것이다. 따라서 식 (3)에서 피복콘크리트 의 단면적으로 고려하면 식 (4)와 같이 표현할 수 있다.

$$
P_{u}=0.85 f_{c o} A_{g}+8.2 \frac{f_{y} A_{s p}}{d_{s} s}+f_{y} A_{s t}
$$

식 (4)는 피복콘크리트 단면적으로 고려한 철근콘크리트의 압축하중으로서 이 식을 식 (2)에 대입하면 RCFFT의 압축강 도를 추정할 수 있다. 그러나 이러한 방법은 FRP에 의한 구 속압과 횡방향철근에 의한 구속압을 중복하여 고려하고 있기 때문에 RCFFT의 강도를 보다 크게 추정한다. 따라서 횡방향 철근 및 FRP에 의한 구속압의 크기에 따라 식 (2)는 식 (5), (6)과 같이 구분하여야 한다.

$$
\begin{aligned}
& P_{R C F F T}=P_{u c}+\left(f_{c c}-f_{c o}\right) A_{c} ; \quad f_{l s} \geq f_{l} \\
& P_{R C F F T}=f_{c c} A_{c o}+f_{y} A_{s t} ; \quad f_{l s}<f_{l}
\end{aligned}
$$

식 (5)에서 $A c$ 는 횡방향철근과 $\mathrm{FRP}$ 사이에 존재하는 피복 콘크리트의 단면적이며, 띠철근에 의한 구속압 $\left(f_{l s}\right)$ 이 FRP에 의한 구속압 $\left(f_{l}\right)$ 보다 큰 경우로서 심부콘크리트는 철근에 의한 구속효과만을 고려하고, 피복콘크리트는 FRP에 의한 구속효과 만을 고려하도록 구성하였다. 또한, 식 (6)은 FRP에 의한 구 속압이 철근에 의한 구속압 보다 큰 경우로서 단면내 모든 콘 크리트에 대해 FRP에 의한 구속효과만을 고려하여 식을 구성 하였다. 식 (5), (6)에서 FRP로 구속된 콘크리트 합성부재 (CFFT)의 압축응력(fcc)은 기존 연구결과[4](식 (7))를 적용하여 추정하였다. 


$$
f_{c c}=f_{c o}\left\{0.7+3.7\left(\frac{f_{l}}{f_{c o}}\right)\right\}
$$

또한, 횡방향철근에 의한 구속압 및 FRP에 의한 구속압은 역학적으로 각각 식 (8), (9)에 의해 결정되어지며, 식 (9)에서 $f f r p, t f r$ 는 각각 FRP의 원주방향 파단응력 및 두께 이고, $d$ 는 $\mathrm{FRP}$ 내부 직경이다. 이 연구에서 제안한 강도평가식과 실험결 과를 비교하면 Table 3 과 같다.

$$
\begin{aligned}
& f_{s l}=\frac{2 f_{y} A_{s p}}{d_{s} s} \\
& f_{l}=\frac{2 f_{f r p} t_{f r p}}{d}
\end{aligned}
$$

Table 3 Comparison of results

\begin{tabular}{c|c|c|c}
\hline \hline No. & Test Result $(k N)$ & Proposed Eq. $(k N)$ & Difference $(\%)$ \\
\hline $\mathrm{RV}_{0}$ & $2,399.8$ & $2,314.1$ & 3.7 \\
\hline $\mathrm{RV}_{1}$ & $3,937.8$ & $3,887.8$ & -1.3 \\
\hline $\mathrm{RV}_{2}$ & $5,224.5$ & $5,110.9$ & -2.2 \\
\hline $\mathrm{RV}_{3}$ & $7,454.0$ & $7,603.1$ & 2.0 \\
\hline
\end{tabular}

Table 3에서 $\mathrm{RV}_{0}$ 실험체에 대해 예측된 압축강도는 $\mathrm{FRP}$ 가 보강되어 있지 않은 실험체이기 때문에 식 (3)에 의한 결과이 며, 나머지 실험체에 대해서는 식 (5), (6)을 통해 예측한 결과 이다. Table 3의 결과로부터 식 (5), (6)은 실험결과와 비교할 때 약 $2.5 \%$ 이내의 차이로 매우 정확한 값을 예측하는 것으로 나타났다.

\section{RCFFT의 휨성능 평가}

RCFFT는 FRP 보강에 의한 구속효과로 콘크리트가 파괴 된 후에도 단면손실이 발생하지 않아 갑작스런 내력저하는 발생하지 않기 때문에 결과적으로 연성능력과 에너지 흡수능 력이 우수해진다. 이러한 거동특성을 조사하기 위해 이 연구 에서는 RCFFT에 대한 준정적 휨실험을 수행하였다.

\section{1 실험체 제작 및 실험방법}

준정적 휨실험체의 직경은 모두 $300 \mathrm{~mm}$, 길이는 $1,500 \mathrm{~mm}$ 로 제작된 실험체의 종류 및 제원은 Table 4에 정리하여 나 타내었다.

Table 4 Type of specimens

\begin{tabular}{c|c|c|c}
\hline \hline No. & $t_{f r p}(\mathrm{~mm})$ & 종방향철근 갯수 & 횡방향철근 간격 $(\mathrm{mm})$ \\
\hline $\mathrm{RH}_{0}$ & 0 & 6 & 100 \\
\hline $\mathrm{RH}_{1}$ & 1.25 & 6 & 100 \\
\hline $\mathrm{RH}_{2}$ & 2.50 & 6 & 100 \\
\hline
\end{tabular}

RCFFT 휨실험체는 압축실험체와 직경 및 구성은 동일하 지만 수평하중을 재하하기 위한 실험체 고정을 위해 하단부 에 콘크리트 블록 기초을 통해 실험체와 합성되도록 제작하 였다. 실험체의 길이를 제외한 형상 및 치수 등은 Fig. 4에 나타내 바와 동일하며, 실험체 상단부에 하중을 재하하기 위 한 콘크리트 블록을 별도로 제작하여 실험체와 합성시켰다.

$\mathrm{RCFFT}$ 의 휨실험에서 기초 상단으로부터 하중재하 지점까 지 높이는 $1.5 \mathrm{~m}$ 이고, 실험체의 횡변위를 측정하기 위해 하중 가력방향의 반대편 하중재하 위치에 LVDT를 설치하였다. 또한, 수평방향 하중재하장치는 최대 스트로크(Stroke) $\pm 250 \mathrm{~mm}$, 최대 하중 $1,000 \mathrm{kN}$ 의 용량으로 실험체의 가력부분과 동일한 높이로 내력벽에 설치하여 실험을 수행하였다. 수평하중은 최 외곽 철근이 항복하는 변위를 항복변위로 가정하여 항복 변위만큼 증가시키며, $0.002 \mathrm{~Hz}$ 로 1cycle씩 재하시킨 후 다음 단계로 진행하였다. 준정적 휨실험방법 및 횡방향 변위수준 (Drift level)은 Fig. 7에 나타내었으며, RCFFT에 대해 압축 재로서 실제 현상과 유사한 조건을 부여하기 위해 일정한 크 기의 축방향 하중을 재하한 상태에서 수평하중을 재하하였 다. 축방향 하중은 $3,500 \mathrm{kN}$ 용량의 하중재하장치(Actuator)를 사용하여 이동하중과 고정하중에 해당하는 $711.7 \mathrm{kN}$ 의 하중을 재하하였다. 이때 축하중이 휨실험 진행도중 일정하게 작용 할 수 있도록 하중재하장치와 실험체가 일체로 거동할 수 있 도록 하였다.

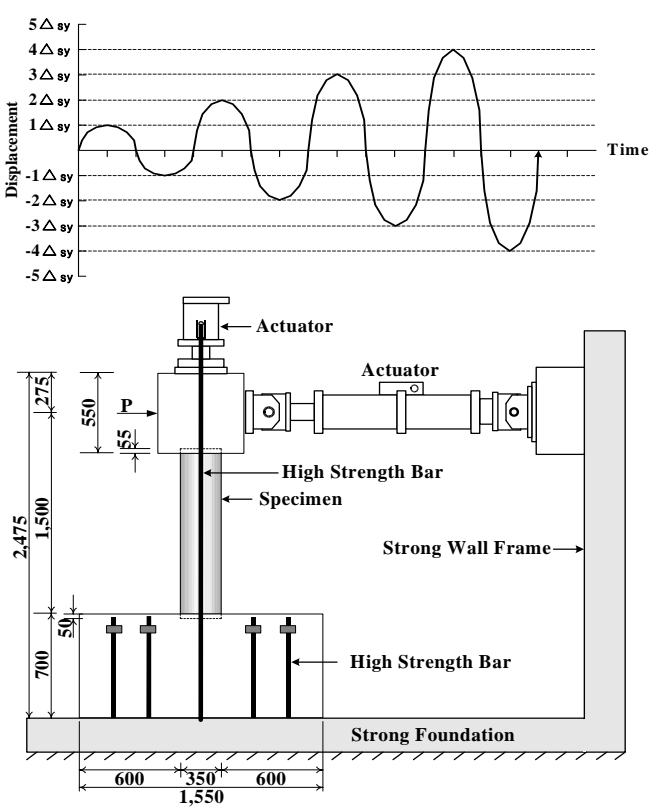

Fig. 7 Loading history and test set-up. 


\section{2 준정적 휨실험 및 결과}

RCFFT에 대한 휨성능 평가는 준정적 휨실험을 통해 수 행하였으며, 실험체의 파괴시 변위를 확인하기 위해 설치된 실험체와 비교하여 Fig. 8에 나타내었다.
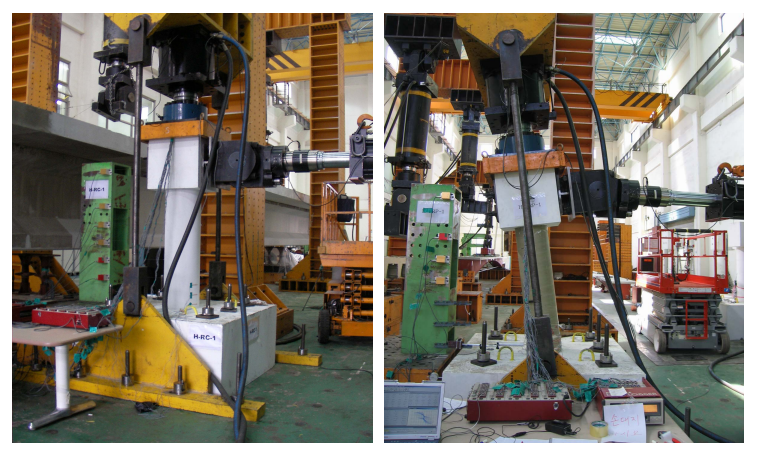

Fig. 8 Lateral displacement of RCFFT column.

RCFFT의 준정적 휨실험 결과 $\mathrm{RH} 0$ 실험체는 콘크리트에 서 수평방향 및 사인장 균열이 발생한 후 콘크리트의 박리현 상이 발생하기 시작하였다. 단면손실이 증가하면서 결국 종 방향 철근에 과도한 변위가 발행하여 파괴되는 전형적인 철 근콘크리트 휨파괴 거동을 나타내었다.

RCFFT 실험체인 $\mathrm{RH}_{1}, \mathrm{RH}_{2}$ 실험체에서도 유사한 파괴거 동을 보였으나 FRP에 의해 내부콘크리트가 구속되어 있어 $\mathrm{RH} 0$ 실험체와는 달리 하중이 크게 감소하지 않고 변위가 증 가하였다. RCFFT 실험체의 파괴 진전 형태는 기둥과 하부 기초가 연결되는 소성힌지 부분에서 $\mathrm{FRP}$ 의 에폭시 수지에서 횡방향 균열이 발생하기 시작하여 결국 FRP의 파단에 의해 최종적으로 파괴되었다. 각 실험체의 최종 파괴형태는 Fig. 9 에서 보여주고 있다.

실험결과 측정된 데이터로부터 실험체에 따른 하중-횡변 위 이력곡선을 Fig. 10에 나타내었고, 주요 값들은 Table 5에 정리하여 나타내었다.

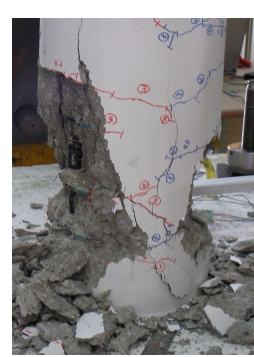

(a) RHO

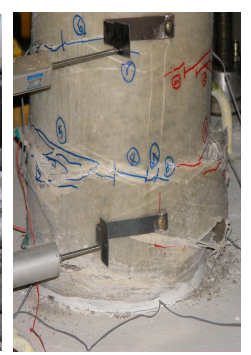

(b) RH1

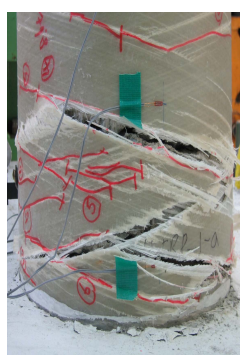

(c) RH2
Fig. 9 Failed shape.

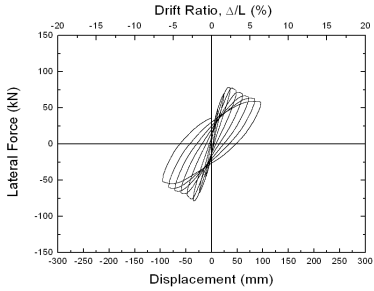

(a) RHO

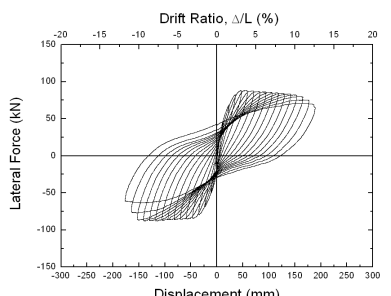

(b) RH1

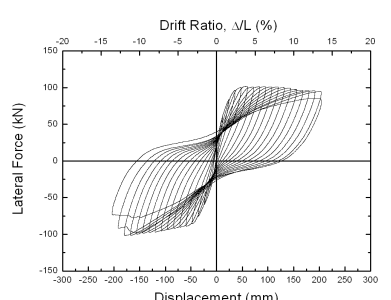

(c) RH2

Fig. 10 Hysteresis loop.

실험결과 $\mathrm{RH} 0$ 실험체인 경우 최대하중에 도달한 후 하중 저항성능이 급격이 감소하는 반면 $\mathrm{RH}_{1}, \mathrm{RH}_{2}$ 실험체는 최대 하중에 도달한 후에도 하중저항성능이 감소하지 않고 충분한 연성을 보인 후 파괴에 이르렀다. 따라서 RCFFT 실험체가 기존 RC 실험체보다 연성 및 에너지 흡수능력이 우수한 것 으로 평가되었다.

연성을 나타내는 지표인 변위연성도는 항복변위에 대한 극 한변위를 의미하는 것으로서 항복변위는 수평방향 최대하중의 $75 \%$ 에 해당하는 변위, 극한변위는 수평방향 최대하중의 $20 \%$ 가 저하되었을 때의 변위이다. Table 5에서 $\mathrm{RH} 0$ 실험체인 경 우 변위연성도는 3.43 으로 측정되었으나 $\mathrm{RH}_{1}, \mathrm{RH}_{2}$ 실험체는 각각 6.33, 7.69로 측정되어 $\mathrm{RC}$ 부재에 비해 RCFFT 부재가 우수한 구조적 성능을 확보하고 있는 것으로 평가되었다.

Table 5 Test result

\begin{tabular}{c|c|c|c|c|c}
\hline No. & $\begin{array}{c}\text { 최대하중 } \\
(k N)\end{array}$ & $\begin{array}{c}\text { 항복변위 } \\
(\mathrm{mm})\end{array}$ & $\begin{array}{c}\text { 파괴하중 } \\
(\mathrm{kN})\end{array}$ & $\begin{array}{c}\text { 파괴변위 } \\
(\mathrm{mm})\end{array}$ & $\begin{array}{c}\text { 변위 } \\
\text { 연성도 }\end{array}$ \\
\hline $\mathrm{RH}_{0}$ & 78.67 & 23.57 & 62.94 & 80.79 & 3.43 \\
\hline $\mathrm{RH}_{1}$ & 88.02 & 28.76 & 70.42 & 182.05 & 6.33 \\
\hline $\mathrm{RH}_{2}$ & 101.87 & 26.53 & 81.50 & 204.09 & 7.69 \\
\hline
\end{tabular}




\section{3 결과분석}

$\mathrm{RCFFT}$ 에 대한 휨거동을 비교하기 위해 각 실험체별로 하중재하점에서 측정한 변위를 Fig. 11에 나타내었다. Fig. 11 에서 $\mathrm{FRP}$ 의 보강두께가 $1.25 \mathrm{~mm}, 2.5 \mathrm{~mm}$ 증가할 경우 보강 하지 않은 실험체에 비해 파괴하중은 약 $11.9 \%, 29.5 \%$ 증가 하였으며, 연성도는 약 $84.5 \%, 124.2 \%$ 의 증가를 나타내었다. 따라서, 철근콘크리트 기둥에 대한 $\mathrm{FRP}$ 의 보강은 압축성능 뿐만 아니라 휨성능 및 내진에 대한 저항성 등을 향상시켜 설계 및 시공시 안전성을 더욱 향상시킬 수 있는 것으로 조 사되었다.

RCFFT를 건설분야 기둥부재로 사용하기 위해서는 우선 파괴모드에 대한 검토가 필수적으로 선행되어야 한다. 일반 적으로 기둥은 장주와 단주로 구분되며, 단주는 재료에 의한 파괴가 발생하고 장주는 좌굴에 의한 파괴가 발생한다. 이러 한 검토를 수행하기 위해서는 RCFFT의 휨강성을 결정해야 하지만 아직까지 이러한 연구는 수행된 바 없다. 따라서 이 연구에서는 RCFFT와 유사한 구성을 갖는 콘크리트 충전 강 관부재에 대해 AISC, Specification for Structural Steel Buildings (2005)[5]에서 제안하고 있는 비례한계내에서의 휨 강성 예측방법과 유사하게 식 (10)과 같이 RCFFT 부재에 대한 휨강성 추정식을 제안하였다.

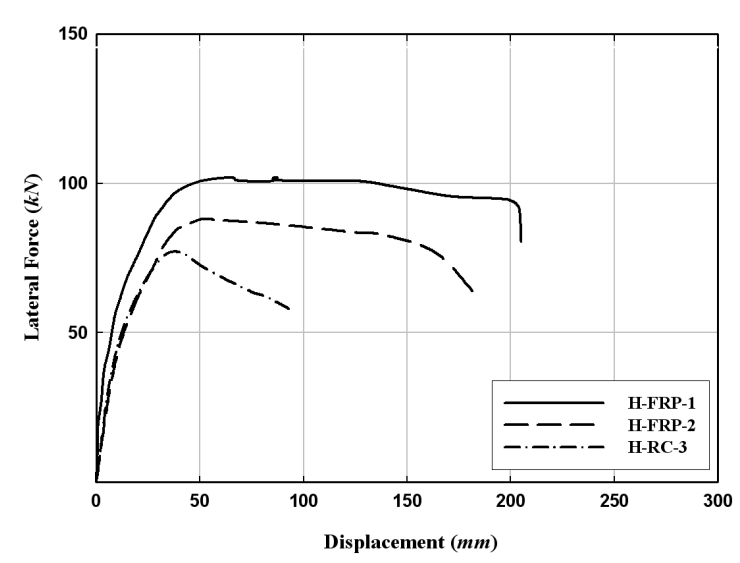

Fig. 11 Lateral load vs. displacement.

$$
E I_{e f f}=E_{f r p} I_{f r p}+E_{s} I_{s r}+C_{3} E_{c} I_{c}
$$

식 (10)에서 $E_{f r p}, E_{s}, E_{c}$ 는 각각 $\mathrm{FRP}$, 강재, 콘크리트의 탄 성계수이고, $I s r, I c, C 3$ 는 각각 단면 중립축에 대한 철근 및 콘크리트 단면의 단면2차모멘트, 감소계수이며, Ifrp는 FRP의 단면2차모멘트로서 AISC (2005)[5]에서는 식 (10)의 첫 번째 항을 강관에 대한 탄성계수와 단면2차모멘트의 곱으로 표현 한 것을 이 연구에서는 RCFFT의 단면특성을 고려하여 FRP 에 대한 항으로 구성하였다. 또한, 식 (10)의 감소계수 $C_{3}$ 는 식 (11)에 의해 결정하였다.

$$
C_{3}=0.6+2\left(\frac{A_{s}}{A_{c}+A_{s}+A_{f r p}}\right) \leq 0.9
$$

식 (11)에서 $A c, A s, A_{f p}$ 는 각각 콘크리트, 철근, $\mathrm{FRP}$ 의 단 면적이다.

휨강성은 부재가 탄성범위내에서 거동하고 있을 때를 기 준으로 평가된다. 따라서, 식 (10)을 통해 예측한 휨강성을 검증하기 위해 Fig. 11에 나타낸 하중-횡변위 곡선의 초기 기울기와 비교하여 Table 6에 나타내었다.

Table 6 Comparison of flexural stiffness

\begin{tabular}{c|c|c|c}
\hline $\mathrm{tfrp}$ & $\begin{array}{c}\text { 실험결과 } \\
k N \cdot m^{2}(\mathrm{~A})\end{array}$ & $\begin{array}{c}\text { 예측결과 } \\
k N \cdot m^{2}(\mathrm{~B})\end{array}$ & {$[(\mathrm{A}-\mathrm{B}) / \mathrm{A}] \times 100$} \\
\hline $1.25 \mathrm{~mm}$ & 9,547 & 8,455 & 11.4 \\
\hline $2.50 \mathrm{~mm}$ & 8,274 & 8,330 & -0.7 \\
\hline
\end{tabular}

캔틸레버보의 자유단에 집중하중 $\mathrm{P}$ 를 작용시키면 최대처 짐은 자유단에서 발생하고 그 값은 $P L^{3} / 3 E I$ eff이다. 이때 휨강 성(S)은 단위변위를 일으키는데 필요한 힘이므로 식 (12)와 같이 나타낼 수 있다.

$$
S=\frac{3 E I_{e f f}}{L^{3}}
$$

Table 6에서 실험결과에 의한 기울기는 Fig. 12 로부터 조 사한 최대하중의 $40 \%$ 까지의 초기 선형 기울기이며, 예측결 과는 식 (10)에 의해 결정한 휨강성을 식 (12)에 대입하여 결정한 수치이다.

AISC에서 제안하고 있는 합성부재에 대한 휨강성 예측방 법과 유사하게 RCFFT의 휨강성을 추정한 결과 하중-횡변위 곡선의 기울기는 실험결과와 비교할 때 약 $11 \%$ 의 차이를 나 타내었으며, 이 결과는 RCFFT에 대한 휨강성을 매우 효과적 으로 예측할 수 있는 것으로 나타났기 때문에 RCFFT 압축 부재의 휨해석 및 장주효과 검토를 위한 좌굴해석에 사용할 수 있을 것으로 판단된다.

\section{5. 결 론}

RCFT는 기존 CFFT에 대해 휨에 대한 하중저항성능을 향 상시키기 위해 내부에 철근을 배근한 부재로서 이 연구에서 는 RCFFT에 일축압축실험 및 준정적 휨실험으로 수행하여 구조적 거동을 조사하였다. 실험결과 RCFFT는 기존 RC 부 재에 비해 압축 및 휨성능이 우수한 것을 확인하였으며, 압 축강도 및 휨강성을 추정하기 위한 방법을 제안하였고, 실험 결과와 비교하여 타당성을 검증하였다. 
후 기

이 연구는 한국건설교통기술평가원에서 지원하는 “건설기술 혁신사업” 연구과제로 수행된 것이며, 연구비 지원에 감사 드립니다.

\section{참고문헌}

1) 박주경, $\mathrm{FRP}$-콘크리트 합성 압축재의 거동평가 및 예측에 관한 실험적 연구, 박사학위논문, 홍익대학교 대학원, 2004.

2) 현대건설(주), 콘크리트 충진 FRP-스트럿을 가진 PSC 박스거더의 안전성 평가, 연구보고서, 2007.

3) Lin, H. J. and Liao C. I., "Compressive Strength of Reinforced Concrete Column Confined by Composite Materials," Composite Structures, 2007. No. 65, pp. 239-250.

4) 박종화, PSC 박스거더교 적용을 위한 FRP 스트럿의 압축 거동 평가, 박사학위논문, 한양대학교 대학원, 2010.

5) AISC, Specification for Structural Steel Building, American Institute of Steel Construction, 2005.

6) Park, R. and Paulay, T., Reinforced Concrete Structures, John Wiley \& Sons, New York, 1975.

7) 주형중, 이승식, 김영호, 박종화, 윤순종, “콘크리트 충전 FRP 원통관의 압축거동에 관한 실험적 연구,” 한국복합 재료학회지, 제21권, 제3호, 2008, pp. 24-30. 